\title{
Planning and selection of green roofs in large urban areas. Application to Madrid metropolitan area ${ }^{\not /}$
}

\author{
Velá zquezJ., Anza P., Gutiérrez J., SánchezB., Hernando A., García-Abril A.
}

\section{A R T I C L E I N F O}

\section{Keywords:}

Green roofs

LIDAR

MSPA

Pollution

Urban planning

Urban population

\begin{abstract}
A B S T R A C T
Due to the numerous environmental problems facing today's society, and especially urban areas, green roofs are presented as an adequate technique to fight the consequences of pollution, traffic and lack of green areas. These green structures help to reduce the effects of Urban Heat Island, to decrease noise and atmospheric pollution, to protect homes from isolation and cold; they also capture rainwater and improve biodiversity. A new methodology is presented to select the best location of green roofs in large cities. In the first phase, this methodology helps to determine the most suitable neighborhoods, analyzing four main variables of interest in urban environs: pollution, traffic, green areas and population. In order to benefit a greater number of inhabitants, the neighborhoods with the worst air quality, more traffic, less green áreas and higher population density, are selected. In the second phase, we used LIDAR technology to identify available roofs for the installation of the green roofs according to the height and roof typology of the buildings. To select the optimal roofs, connectivity analysis techniques were used. The results show that the most conflictive neighborhoods from the environmental point of view are those located in the city center, so they result the ideal places for the location of green roofs. In general, all neighborhoods except one presented high connectivity values. This methodology helps to improve the connectivity of the green spaces of Madrid, favoring the dispersion of plant and animal species, air quality and promoting sustainable and quality urban development.
\end{abstract}

\section{Introduction}

Today, most of the world's population lives in urban areas characterized by a high degree of transformation (United Nations, 2013), which generates a negative impact on quality of life (Grimm et al., 2008; Tyrväinen et al., 2014). The replacement of natural elements with construction materials such as concrete, cement or asphalt alters the balance of solar radiation in cities, triggering an effect known as Urban Heat Island (UHI), which causes temperatures in cities to increase up to $10^{\circ} \mathrm{C}$ (Chun and Guldman, 2014; Tumini, 2010). In addition, greenhouse gas emissions caused by traffic volume, industry and heavy electricity consumption are present. The problem begins when these emissions (especially NOx - which is responsible for the generation of tropospheric ozone - and hydrocarbons) are added to high temperatures, generating the effect known as photochemical smog. The heat island phenomenon is therefore very negative for the health of the inhabitants of large cities because it encourages the appearance of this photochemical smog. In addition, the heat accumulated in buildings, sidewalks and roads, as well as their spatial arrangement, alters the wind regime within a city, slowing it down and increasing its turbulence, which ultimately means that pollutants are unable to disperse and tend to concentrate on large clouds over the city (Britter and Hanna, 2003).

Due to nature's ability to constantly seek balance, solutions based on it are the best tool for solving the environmental problems of urban areas. These nature-based solutions include the technique of green roofs based on vegetation (usually herbaceous) covering all or part of the roofs of buildings, improving the habitat of cities, reducing energy consumption, and intercepting a large amount of water from rainfall (Constanzo et al., 2016; Roman et al., 2016).

Although green roofs are presented as a novel technology, they have been used for centuries in the Scandinavian countries to insulate

\footnotetext{
This article is part of a special issue entitled "Urban Green Infrastructure - Connecting People and Nature for Sustainable Cities" published at the journal Urban Forestry \& Urban Greening 40C, 2019.
} 


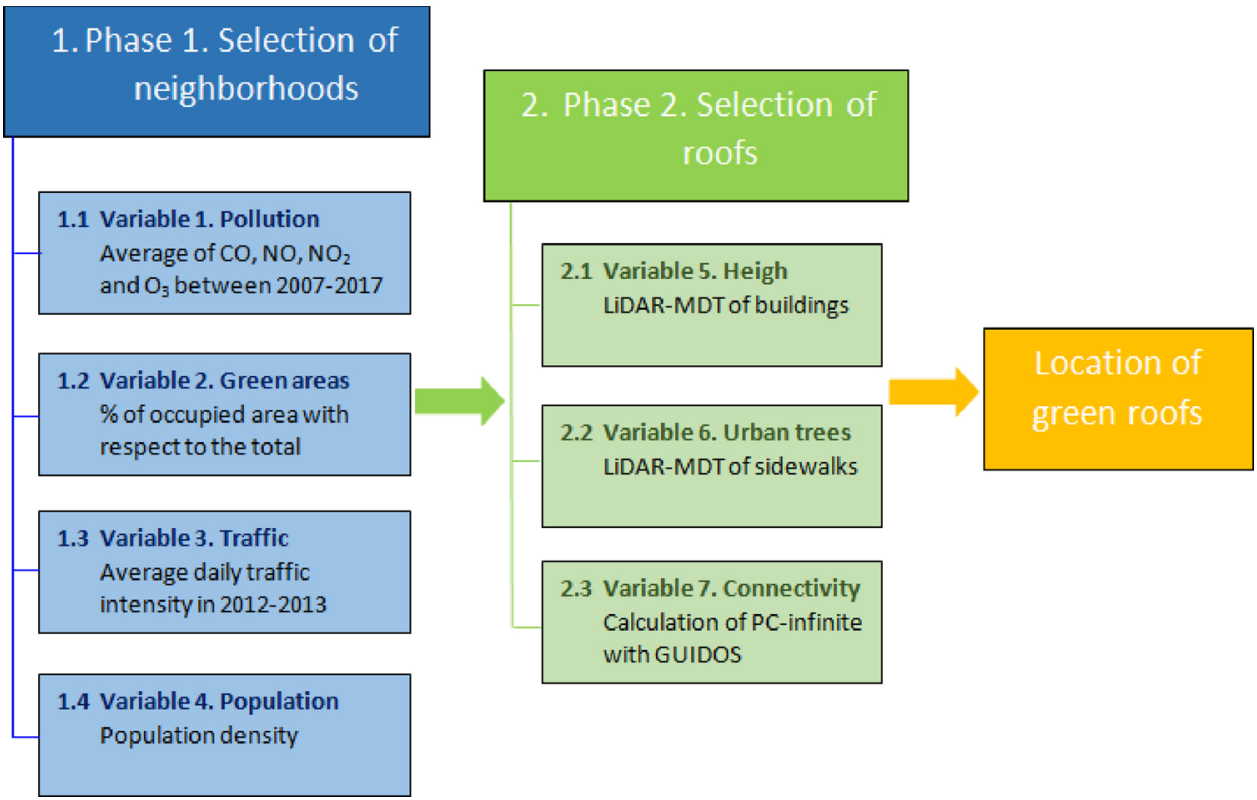

Fig. 1. Diagram of the green roof location methodology.

dwellings from the cold (Minke, 2004); however, it was not until the 1960 's when use of green roofs as a corrective measure of the environmental quality of cities began to spread. It is currently estimated that in Germany, $10 \%$ of the roofs are green roofs (Berardi et al., 2014). Toronto, Canada, was the first city to legislate on this matter, achieving more than 1.2 million square meters of green roofs on different types of buildings (Toronto City Planning Division, 2013; Peck, 2009; Currie and Bass, 2008). Later, Switzerland and Copenhagen also introduced laws in relation to green roofs (Brenneisen, 2006; Berardi et al., 2014).

Thanks to the environmental, aesthetic, sociological and economic benefits of this technique (Constanzo et al., 2016; Karachaliou et al., 2016; Ziogou et al., 2017) green roofs have been gaining followers little by little. In terms of environmental benefits, they contribute to the control of rainwater and rainfall (Berardi et al., 2014; Sims et al., 2016), reduce rainwater pollution and energy consumption, improve air quality, reduce noise pollution, increase biodiversity and, as already mentioned, mitigate the "Urban Heat Island" effect (Razzaghmanesh et al., 2016). The aesthetic and sociological benefits are associated with the improvement of mental and physical health (Wolch et al., 2014), and the economic benefits lie in the new business opportunities that this technique represents for the construction sector.

Planning of urban green areas in contemporary cities should address the solution of their main environmental problems and also "counteract negative effects of urban sprawl in terms of ineffective land-use and related environmental problems" (Haaland and van den Bosch, 2015). At present, the planning of green areas attempts to bring nature into urban spaces and integrate it where people live and work, promoting the well-being of the citizens and the sustainability of the city in which they live (Chiesura, 2004; James et al., 2009; Sanesi and Chiarello, 2006).

All the aforementioned benefits and the unstoppable growth of the cities, with the consequences that derive from it, justify the use of green roofs as a method to fight against the problems derived from the pollution of large cities (Getter and Rowe, 2006). The main objective of this study is therefore to develop a methodology that allows selection of the ideal location of green roofs, and that could be applied in any urban area. This methodology was applied in the city of Madrid and is based on four major stages: "Study of the city's environmental situation", "Selection of the target neighborhood / $\mathrm{s}$ " (depending on their environmental and social characteristics), "Selection of roofs for the location of green roofs" (depending on their feasibility and the search for the greatest benefit in environmental and social terms), and "Analysis of the benefits of green roofs for the functional connectivity of the urban landscape ". Based on the four previous stages, this study aims to establish the criteria for neighborhood and roof selection.

\section{Material and methods}

\subsection{Study area}

The study focused on the city of Madrid, the capital of Spain. According to data from the Municipal Population Register of Madrid in 2017 , the city has an area of $60,436.7$ ha and a population of 3,182,175 inhabitants. The territory is divided into 21 districts which are in turn divided in 128 neighborhoods. The city is located to the south-east of the Sierra de Guadarrama, at an elevation of $657 \mathrm{~m}$ above sea level. Due to its geographical location, it has a continental Mediterranean climate, which causes less rainfall and greater thermal amplitude.

It should be noted that the climate is greatly influenced by excessive urbanization, which has made Madrid one of the main Urban Heat Islands (UHI) of Spain and Europe (Tumini, 2010; Peiró et al., 2017). This phenomenon is manifested both day and night, and can generate temperature differences of up to $10{ }^{\circ} \mathrm{C}$ with its surroundings.

In addition, serious pollution episodes have occurred in Madrid in recent years (Querol et al., 2014). The urban design of the city alters the wind regime, creating significant difficulties to disperse pollution; and variations in rainfall caused by global climate change favor the appearance of extreme weather events.

\subsection{Methodology}

The study was based on developing a method to select the ideal location of green roofs, and was applied specifically to the city of Madrid. For this purpose, in the first phase, the most problematic neighborhoods in terms of pollution, traffic, population and green areas were chosen (Huang et al., 1998; Lopera, 2005; Leva, 2005; Ahern, 2007; Kampa and Castanas, 2008; Tanguay et al., 2010; Mattoni et al., 2015). As a result, our actions were aimed at areas with poor environmental quality with potential benefits for a large number of people. After the most problematic neighborhoods had been chosen, the second phase was aimed at locating buildings with certain characteristics in terms of height and availability of roofs for installation of the 

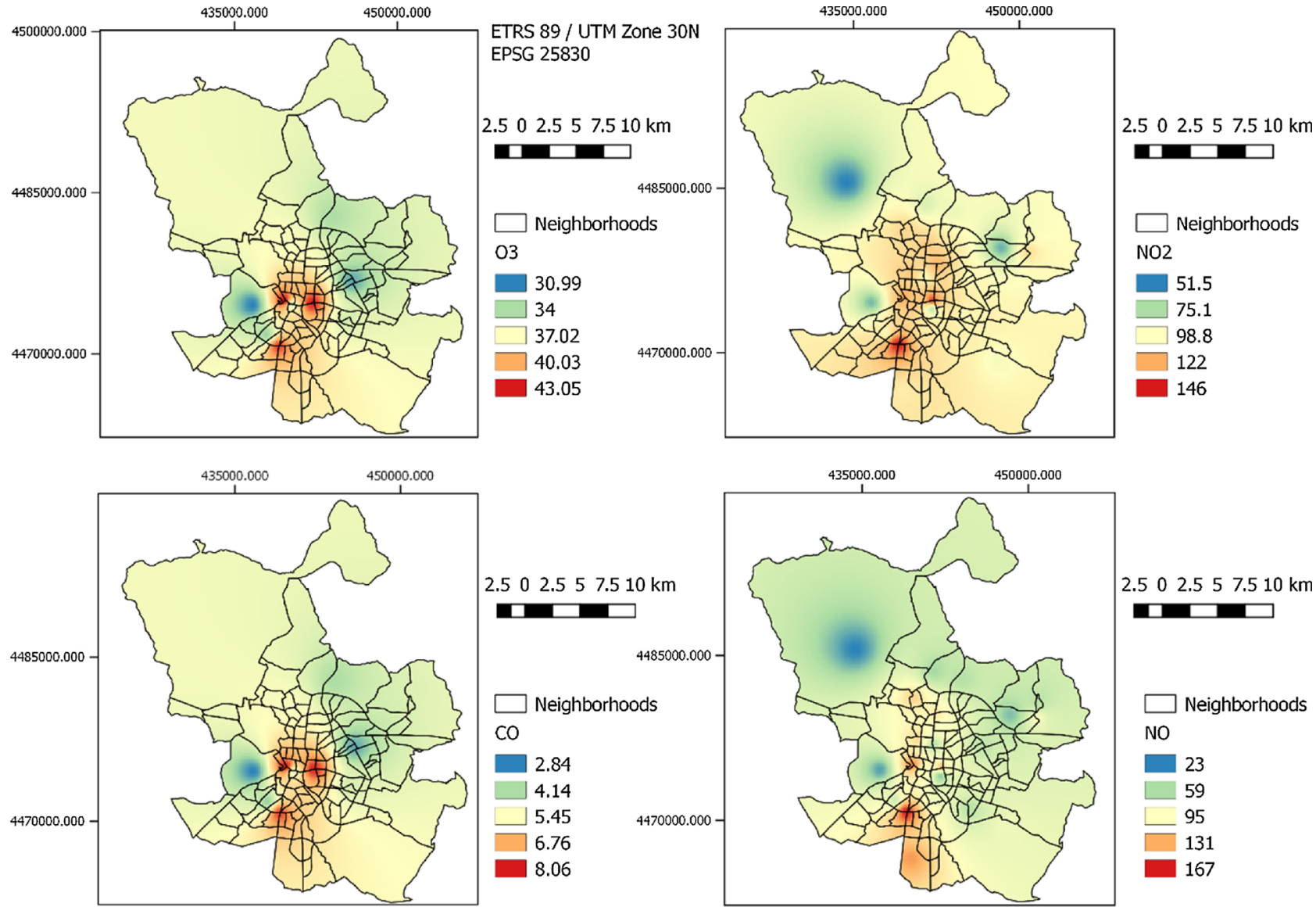

Fig. 2. Map of $\mathrm{O}_{3}, \mathrm{NO}_{2}$, $\mathrm{CO}$ and $\mathrm{NO}$ in Madrid. The data shown represents the average of the last 10 years divided by the legal limit value established by the legislation in force, expressed as a percentage.

green roofs. The final phase of this methodology proposes the improvement of the connectivity of the city's green spaces by connecting these selected roofs with the urban trees in the city (Fig. 1).

\subsubsection{Phase 1. Neighborhood selection}

In this first phase, the most suitable neighborhoods for the installation of green roofs were determined, with the aim of mitigating the environmental problems that Madrid faces. To do this, several characteristics of each neighborhood were compared by means of a multi-criteria assessment, in order to select those that present major problems.

2.2.1.1. Variable 1. Pollution. Madrid has a municipal atmospheric quality monitoring network made up of 26 measuring stations located within the city's municipal limits. These stations measure a large number of pollutants. For this study, only the data for carbon monoxide (CO), nitrogen monoxide (NO), nitrogen dioxide $\left(\mathrm{NO}_{2}\right)$ and ozone $\left(\mathrm{O}_{3}\right)$ was considered relevant (Currie and Bass, 2008; Yang et al., 2008; Li et al., 2010; Rowe, 2011; Li and Babcock, 2014). Although vegetation used on green roofs (usually shrub and herbaceous species) may be more or less effective in reducing other types of air pollutants such as particulates or sulfur compounds (Tripathi and Gautam, 2007; Rowe, 2011; Currie, 2008), these four pollutants were selected because they are the main precursors of photochemical smog.

This study used the hourly data for each pollutant from each station over the last 10 years (2007-2017). Considering that each pollutant has a different unit of measurement and their average values cannot be compared with each other, the values of each pollutant were reclassified in order to be compared with each other and with the rest of the variables. The following equation was used to do this (García,
1999):

$\%$ Pollution $=\frac{\text { average } 10 \text { years }}{\text { Legal Limit }} \times 100$

The data obtained was interpolated for the entire study area in order to obtain a total value that groups the values of each pollutant. This was achieved by a weighted linear summation in which the same weight was assigned to each contaminant compound. As a result, a continuous map was obtained, with pollution contribution values expressed with values ranging from 0 to 100 .

2.2.1.2. Variable 2. Green areas. Green areas are a highly beneficial option for dealing with the environmental problems suffered by cities. They help reduce the heat island effect, absorb large amounts of water from rainfall (reducing surface runoff) and serve as a sink for large amounts of pollutants (Shanahan et al., 2015). In this section, the percentage of green areas in each Madrid neighborhood was calculated, in order to determine the neighborhoods that require a larger plant area.

Through GIS processing of the data on green areas (according to the city council of Madrid), the surface in $\mathrm{m} 2$ occupied by these areas within each neighborhood was determined. To compare this data with the rest of the analyzed variables, the percentage of green areas was calculated by the following equation:

$\%$ Green Area by neighborhood $=\frac{\text { Area of Green Area by neighborhood }}{\text { Total Area of the neighborhood }} \times 100$

2.2.1.3. Variable 3. Traffic. Traffic is one of the city's biggest problems 

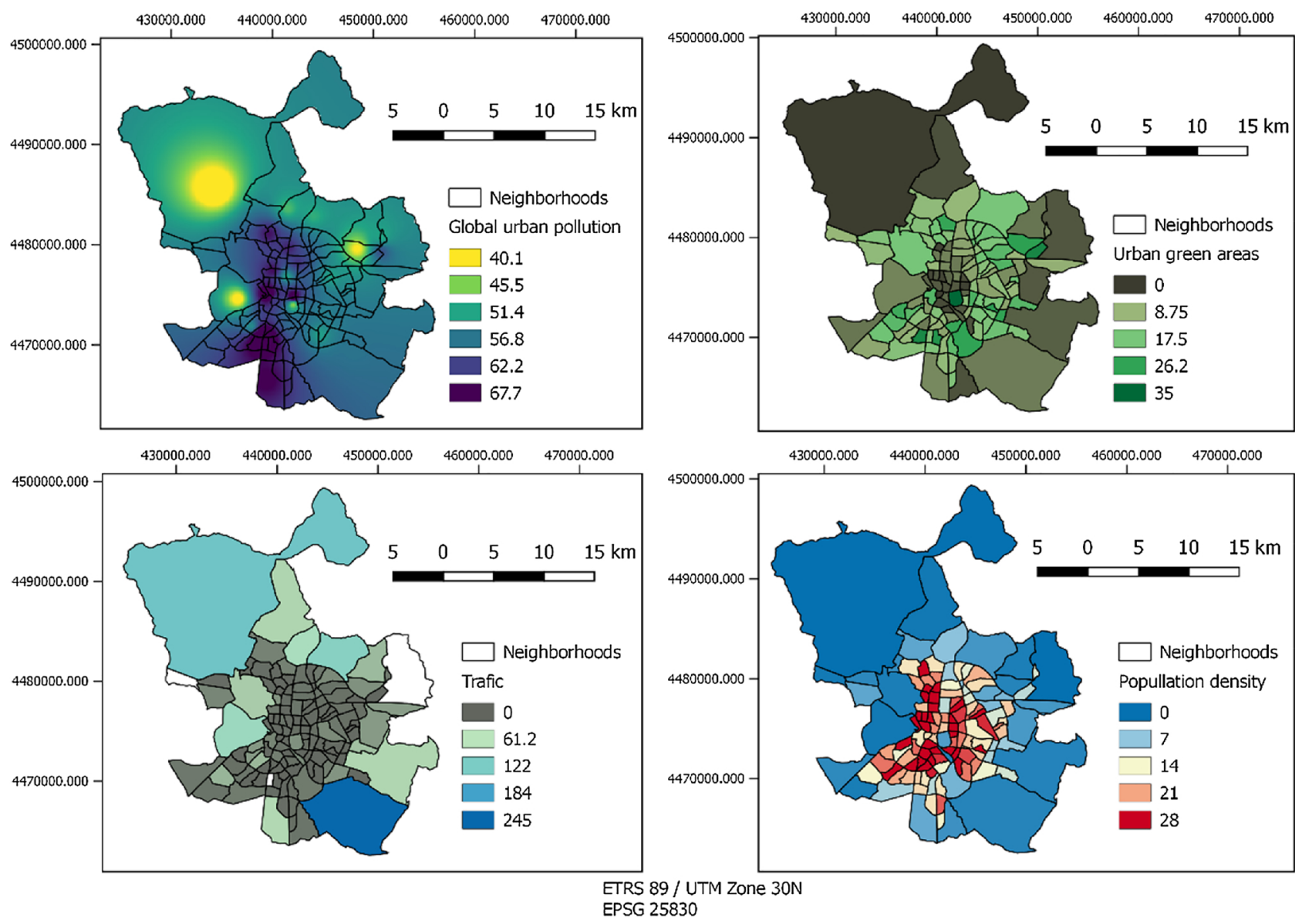

Fig. 3. Results of the variables analyzed in phase 1: a) Overall urban pollution, b) Urban green areas, c) Traffic, d) Population density. All variable values are expressed as percentages.

Table 1

Weights given by each expert and an average of all weights.

\begin{tabular}{|c|c|c|c|c|c|c|c|}
\cline { 2 - 8 } \multicolumn{1}{c|}{} & $\begin{array}{c}\text { Group of } \\
\text { experts } \\
\mathbf{1}\end{array}$ & $\begin{array}{c}\text { Group of } \\
\text { experts } \\
\mathbf{2}\end{array}$ & $\begin{array}{c}\text { Group of } \\
\text { experts } \\
\mathbf{3}\end{array}$ & $\begin{array}{c}\text { Group of } \\
\text { experts } \\
\mathbf{4}\end{array}$ & $\begin{array}{c}\text { Group of } \\
\text { experts } \\
\mathbf{5}\end{array}$ & $\begin{array}{c}\text { Group of } \\
\text { experts } \\
\mathbf{6}\end{array}$ & Average \\
\hline $\begin{array}{c}\text { Green } \\
\text { areas }\end{array}$ & 0.33 & 0.29 & 0.11 & 0.09 & 0.09 & 0.56 & 0.24 \\
\hline Pollution & 0.40 & 0.45 & 0.35 & 0.33 & 0.37 & 0.08 & 0.33 \\
\hline Traffic & 0.17 & 0.17 & 0.35 & 0.36 & 0.33 & 0.08 & 0.24 \\
\hline Population & 0.10 & 0.09 & 0.20 & 0.22 & 0.21 & 0.28 & 0.18 \\
\hline
\end{tabular}

and is one of the main sources of emissions of nitrogen compounds (along with household heating) that encourage the appearance of photochemical smog (Helbing, 2001). To determine traffic levels, we worked with average traffic intensity data for the years 2012-2013 from the official data website of the city of Madrid (datos.madrid.es). The city has a traffic surveillance network composed of 1961 measurement sections throughout the city.

The number of vehicles recorded per neighborhood and the number of measurement sections of each one was determined. By processing the results in GIS, the traffic data was also transformed into a percentage using the following equation:

$\%$ Traffic $=\frac{\text { Total vehicles / neighborhood }}{\text { Number of sections / neighborhood }} \times \frac{\text { Neighborhood area }}{\text { Total area }} \times 100$

Where:

Total vehicles corresponds to the number of vehicles that passed the measurement points in each neighborhood;

Total area is the total surface area of the study area (the municipality of Madrid).

2.2.1.4. Variable 4. Population. In order for the beneficial effects generated by green roofs to affect a larger number of people, the population variable was added.

Population data was downloaded from the website of the Madrid City Council (www.datos.madrid.es). By analyzing this data, the set of inhabitants by neighborhood could be obtained. The objective was to obtain a percentage of the population density in each neighborhood, in order to then compare it with the other variables, applying the following equation:

$\%$ population density $=\frac{\text { population } / \text { neighborhood }}{\text { neighborhood area }} \times 100$

2.2.1.5. Neighborhood selection. Once the four study variables (pollution, green areas, traffic and population) had been calculated and homogenized as a percentage and in raster format, the multi-criteria evaluation was done (Articte, 1995; DeMers, 2002; Malczewski, 2006). 
Table 2

The 10 neighborhoods that obtained the highest scores. The selected neighborhoods are shown in grey. The data on pollution, green areas, population and traffic has already been reclassified on a scale of 0-100.

\begin{tabular}{|c|c|c|c|c|c|c|c|}
\hline DISTRICT & NAME & CODE & POLLUTION & POPULATION & $\begin{array}{c}\text { GREEN } \\
\text { AREAS }\end{array}$ & TRAFFIC & SELECTION \\
\hline $\begin{array}{c}\text { Villa de } \\
\text { Vallecas }\end{array}$ & $\begin{array}{c}\text { Casco } \\
\text { Histórico de } \\
\text { Vallecas }\end{array}$ & 181 & 70,94 & 3,72 & 13,52 & 100,00 & 45,04 \\
\hline Chamberí & Gaztambide & 071 & 77,48 & 99,87 & 2,82 & 0,56 & 43,36 \\
\hline Retiro & Ibiza & 034 & 80,50 & 98,14 & 8,82 & 0,78 & 42,62 \\
\hline Salamanca & Goya & 042 & 80,98 & 85,52 & 1,43 & 1,06 & 42,34 \\
\hline Carabanchel & Opañel & 112 & 100,00 & 65,48 & 13,19 & 1,05 & 42,07 \\
\hline Chamberí & Arapiles & 07 & 78,67 & 94,43 & 6,11 & 0,70 & 41,98 \\
\hline Centro & Embajadores & 012 & 72,22 & 96,83 & 3,59 & 2,71 & 41,39 \\
\hline Chamberí & Trafalgar & 073 & 74,32 & 90,19 & 2,40 & 2,80 & 41,18 \\
\hline Centro & Universidad & 015 & 87,48 & 73,25 & 6,62 & 1,26 & 41,02 \\
\hline Tetuán & Bellas & 061 & 75,91 & 89,64 & 12,60 & 8,98 & 40,62 \\
\hline
\end{tabular}

With this tool, and with the consultation of six groups of experts (a total of 18 experts belonging to different interest groups: 1) nature conservation and environment, 2) urban population with university education, 3) hydrology and climatology academics, 4) forest engineering experts, 5) experts in organic chemistry, biochemistry and environmental chemistry, 6) experts in biodiversity and connectivity), the objective was to select the five neighborhoods in Madrid that present the worst overall pollution and traffic conditions, scarce green areas and the largest populations. Each expert was asked about the importance that should be given to each variable with respect to the other variables, based on Saaty's method of analytical hierarchies (Saaty, 1980). Different profiles were created, one for each expert, in which the most significant characteristics of each one were framed based on their training, age and environmental conservation viewpoint.

Introducing the weights (obtained from the average of all the experts consulted), a final score was calculated for each neighborhood using the following equation:

$w_{i j}=\sum_{j=1}^{n} a_{i j} / \sum_{j=1}^{n} \sum_{i=1}^{m} a_{i j}$

Where $a_{i j}$ represents the weight expressed by each expert in regard to each individual variable in the neighborhood selection methodology.

Finally, the five neighborhoods with the highest scores and with the desired characteristics were chosen. In addition, neighborhoods belonging to different districts were selected, in order to determine the locations of the green roofs in different points of Madrid. These five neighborhoods were selected to serve as an example for the rest of neighborhoods in Madrid, because they are the best targets to address with the environmental problems identified in the four variables included in this study. We selected one neighborhood per district in order to extend the proposed green roof facilities in different areas of the city.

\subsubsection{Phase 2. Roof selection}

After selecting the neighborhoods, in phase two, we proceeded to select the roofs that met the desired conditions for the installation of the green roofs. To do this, the height of the buildings and the height of the urban trees were studied in order to choose the most suitable areas for the installation of green roofs. In addition, connectivity was analyzed in order to improve the connection of green spaces in Madrid.

2.2.2.1. Variable 5. Building height. First, the height and the standard deviation of the buildings of the selected neighborhood were determined to select the roofs. We used LIDAR (Light Detection and
Ranging) technology and the Digital Terrain Model (DTM). Both layers were arranged in raster format and with a resolution of $1 \mathrm{~m}$ per pixel.

For this study we used the open-source LIDAR data available from the Spanish National Orthophoto Program (PNOA) (Arozarena et al., 2005). The point density was 0.5 points $/ \mathrm{m}^{2}$, available in LAS format. This point cloud was processed in LAStools (Isenburg, 2015) to produce a raster with a resolution of $1 \times 1 \mathrm{~ms}$.

2.2.2.1.1. Height. With the LIDAR and the DTM, we proceed to trim the layers to the size of the study area. Only those of the buildings were calculated, eliminating other elements present in the neighborhoods in question: trees, lampposts, kiosks, etc.

Since one of the benefits to be achieved with green roofs is the improvement of the connectivity of the city's green spaces, the buildings that were in a height range between 4 and $25 \mathrm{~m}$ were selected, with heights corresponding approximately with the height of the urban trees (Municipality of Madrid, 2016). This meant that the green roofs were on buildings with similar heights to the urban trees, creating a connected green network connecting the neighborhood.

2.2.2.1.2. Standard deviation. The objective was to select roofs that allow the installation of green roofs, so they had to be as flat as possible. The smaller the standard deviation of the average of its height, the flatter the roof, and, therefore requiring its selection as a location for green roofs. The selection of those buildings with a standard deviation $<5 \mathrm{~m}$ was determined to be necessary, because buildings with higher deviations are considered not to have flat roofs (Rottensteiner et al., 2005; Kim and Shan, 2011).

Finally, those with a standard deviation $>5 \mathrm{~m}$ and heights outside the range of 4-25 meters were eliminated from the layer of buildings (Sugumaran and Voss, 2007; Municipality of Madrid, 2016), generating the layer containing only the selected buildings.

2.2.2.2. Variable 6. Urban trees. Urban trees in cities have enormous social and environmental benefits (Ulmer et al., 2016; Song et al., 2017; Willis and Petrokofsky, 2017). Their presence improves the environmental quality of the urban environment, reducing temperatures, decreasing pollution, reducing noise pollution and generating biodiversity points (Miranda et al., 2017). They also help to improve the mental and physical health of the inhabitants (Kuchelmeister, 2000; Breuste et al., 2014).

In this section, we calculated the height of the urban trees located on the sidewalks and in pedestrian zones of the neighborhood. The trees, identified through the analysis of the LIDAR data, were reclassified in order to obtain the elements of urban trees with a height between 4 and $50 \mathrm{~m}$. A maximum limit of $50 \mathrm{~m}$ was established to 


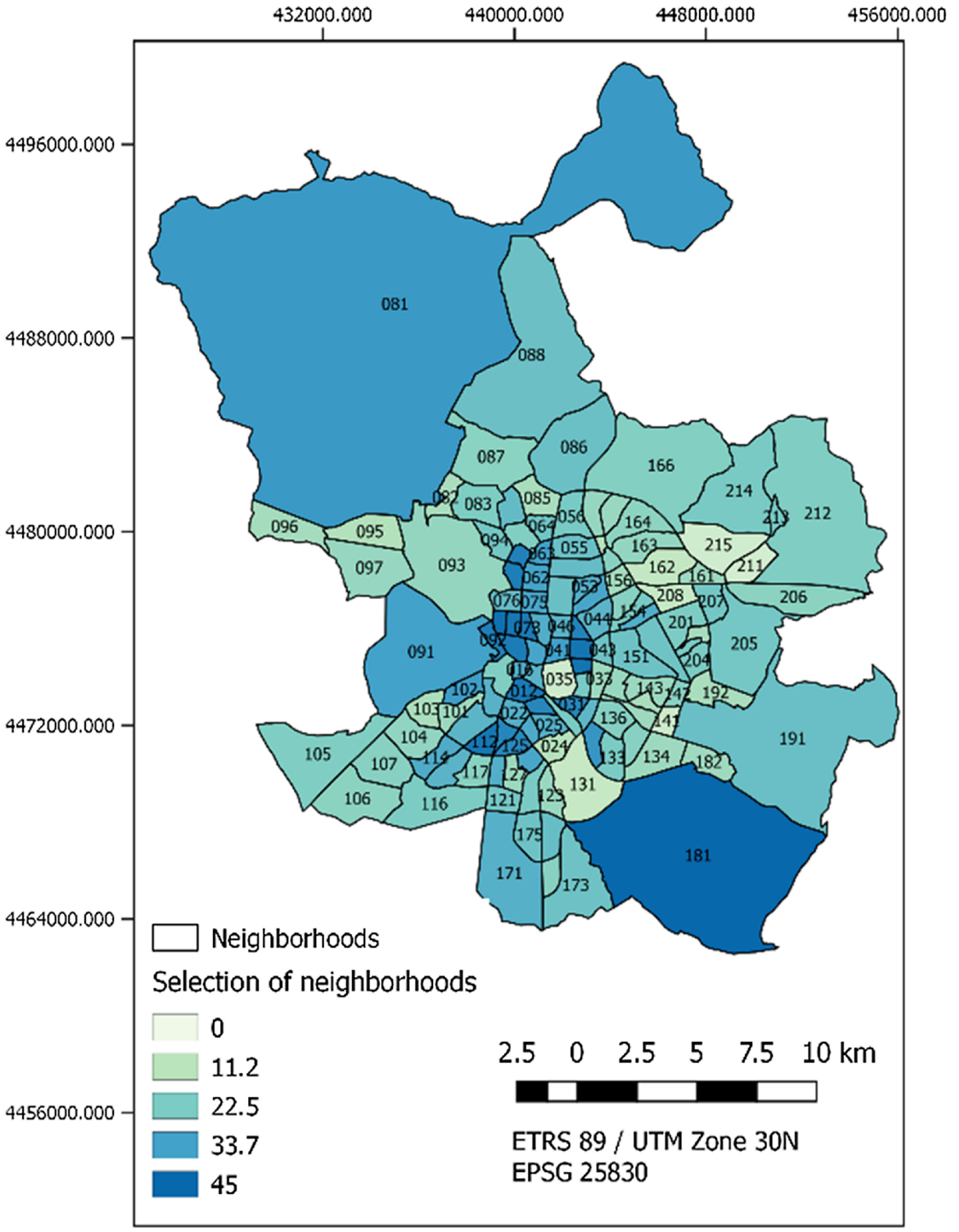

Fig. 4. Score of each neighborhood.

Table 3

Average height (m) and standard deviation (STD) of the buildings of the five selected neighborhoods of Madrid.

\section{\begin{tabular}{|l|l|l} 
NEIGHBORHOOD & AVERAGE STD & HEIGHT (m)
\end{tabular}}

\begin{tabular}{|c|c|c|}
\hline Embajadores & 4.05 & 15.87 \\
\hline Gaztambide & 6.74 & 23.09 \\
\hline Goya & 5.16 & 21 \\
\hline Ibiza & 5.03 & 16.09 \\
\hline Opañel & 3.7 & 12.46 \\
\hline
\end{tabular}

ensure that all urban trees were included, even if they were taller than $25 \mathrm{~m}$ (Sugumaran and Voss, 2007). This was done to select trees located on the sidewalks, which constitute points of connectivity in the neighborhood (Le Roux et al., 2014).
2.2.2.3. Variable 7. Connectivity. The analysis of connectivity focused on the study of structural connectivity (Taylor et al., 1993; Baudry and Merriam, 1988), using the GUIDOS tool for connectivity analysis (Vogt, 2009). The layer on which the connectivity was analyzed contained the buildings selected for the installation of the green roofs, the green areas of the neighborhood and the urban trees selected in raster format. The data was entered as a binary layer of habitat fragments, which was analyzed and transformed according to the MSPA (Morphological Spatial Pattern Analysis) to classify it as nodes, islands, edges, bridges, branches and perforations (Vogt and Riitters, 2017).

For the connectivity analysis, the PC-infinite (Probability of Connectivity) index was calculated. The PC index evaluates the importance of each connection with its node to maintain connectivity (Saura and Pascual-Hortal, 2007). 

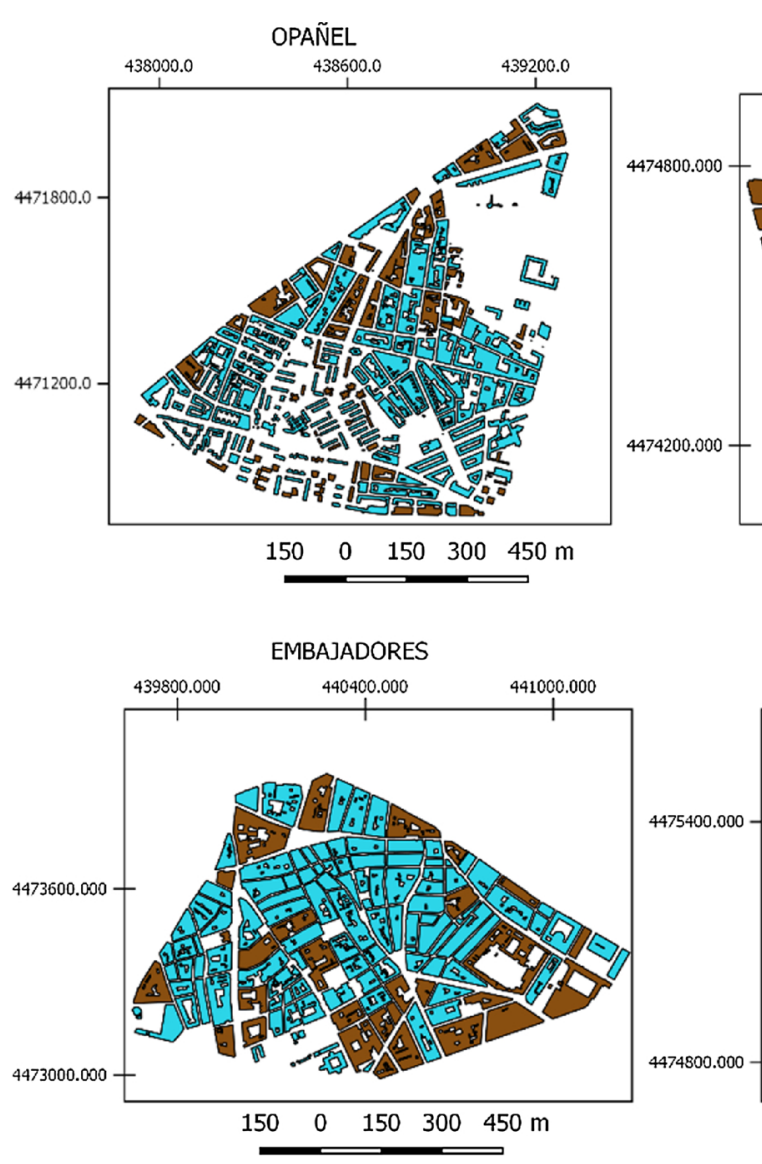
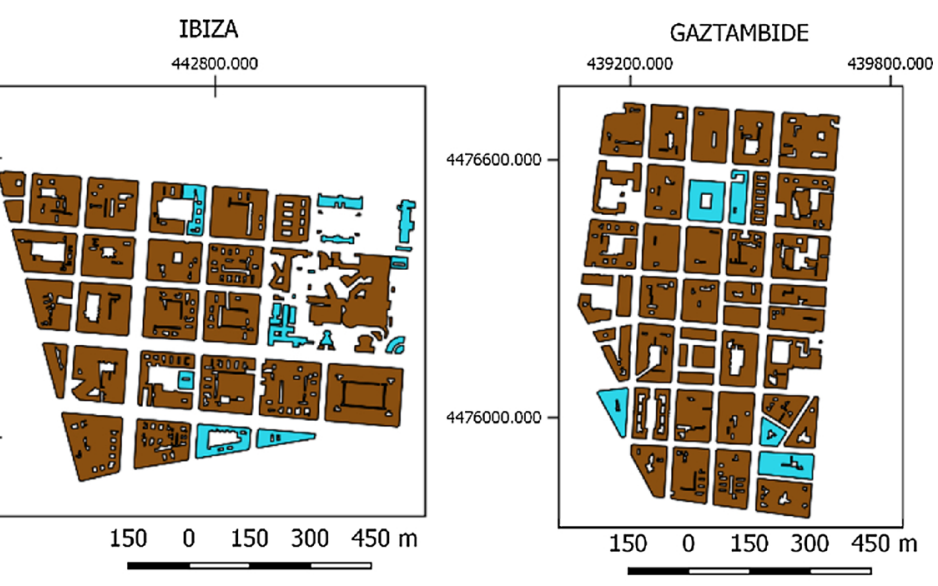

GOYA

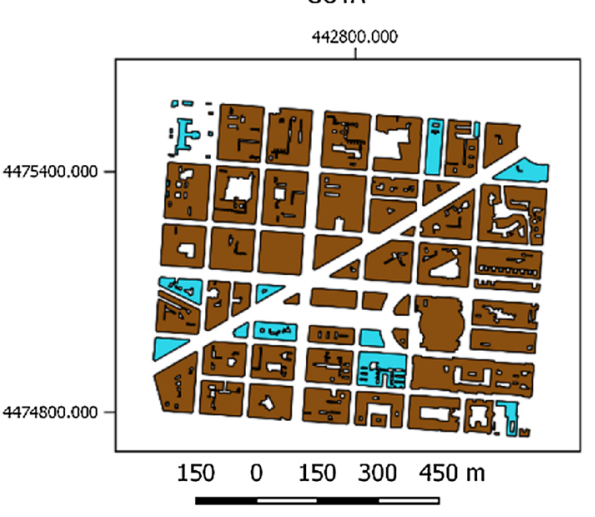

Not selected buildings

ETRS 89 / UTM Zone 30N EPSG 25830
Selected buildings

Fig. 5. Selected buildings in each study district.

$\mathrm{PC}=\frac{\sum_{i=1}^{n} \sum_{j=1}^{n} a_{i} a_{j} p_{i j}^{*}}{A_{L}^{2}}$

Where $a_{i}$ and $a_{j}$ are the areas of habitat patches $i$ and $j$, and AL is the total landscape area (area of the study region, comprising both habitat and non-habitat patches). $p_{i j}^{*}$ is defined as the maximum product probability of all possible paths between patches $i$ and $j$ (including single-step paths).

In addition to the spatial configuration of the landscape, the PC index also considers the dispersal capacity of the species studied. The simplest scenario would be one in which the movement through the joints is always possible (distance of infinite dispersion), and the index of PC-infinite would be used for this. This index is ideal for cases in which the structural connectors are totally effective at driving movement without cost or mortality for the species or flows (Saura et al., 2011). This index is calculated from the results obtained in the MSPA analysis, which is performed for a 1 pixel dispersion band. Taking into account the classifications of the 7 components of the MSPA, only the nodes and bridges are considered in the PC analysis, since only these can contribute to the improvement of connectivity (Saura et al., 2011; Velázquez et al., 2017).When analyzing the importance of the nodes and bridges, the PC- infinite data for each component was obtained, so that the importance of connectivity of the selected buildings for the location of the green roofs could be analyzed. Finally, we proceeded to reclassify PC data based on the maximum value obtained, on a scale of 1 to 100 , to facilitate the comparison of the data.

2.2.2.4. Roof selection. After connectivity analysis on the selected buildings, PC-infinite values were obtained for each one. Depending on the value obtained, the roofs that maximized the connectivity of the green spaces of the city were selected, choosing the buildings with higher PC-infinite values and that fulfilled the previous conditions mentioned in this methodology.

\section{Results and discussion}

\subsection{Phase 1. Neighborhood selection}

\subsubsection{Variable 1. Pollution}

The highest values of $\mathrm{CO}, \mathrm{NO}_{2}$, and $\mathrm{NO}$ are concentrated in the most central neighborhoods of Madrid (Fig. 2). Both gasoline and diesel vehicles, as well as heating devices, generate large amounts of nitrogen compounds, which are emitted into the atmosphere and can cause serious episodes of photochemical smog and even acid rain (Kampa and Castanas, 2008; Aiello et al., 2015). Additional factors include the urban design of the city, the height and spatial arrangement of the buildings, which greatly impedes the movement of air masses and therefore the dispersion of pollution (Britter and Hanna, 2003; Blocken et al., 2008).

When performing the weighted linear summation of the four pollutants studied, the results show how the neighborhoods of Madrid that are most affected by pollution are those located in the central and southern zones (Fig. 3a)), which are also the zones with higher population concentrations and road traffic (Kanaroglou et al., 2005; Beelen et al., 2013).

\subsubsection{Variable 2. Green areas}

The neighborhoods with a smaller surface of green areas are those located in the downtown area and in the suburbs of the city (Fig. 3b)). The centers of most cities correspond to their oldest sections (Krugman, 1993; Stern and Krakover, 1993), so when these neighborhoods were designed, there was no awareness of the social and environmental 


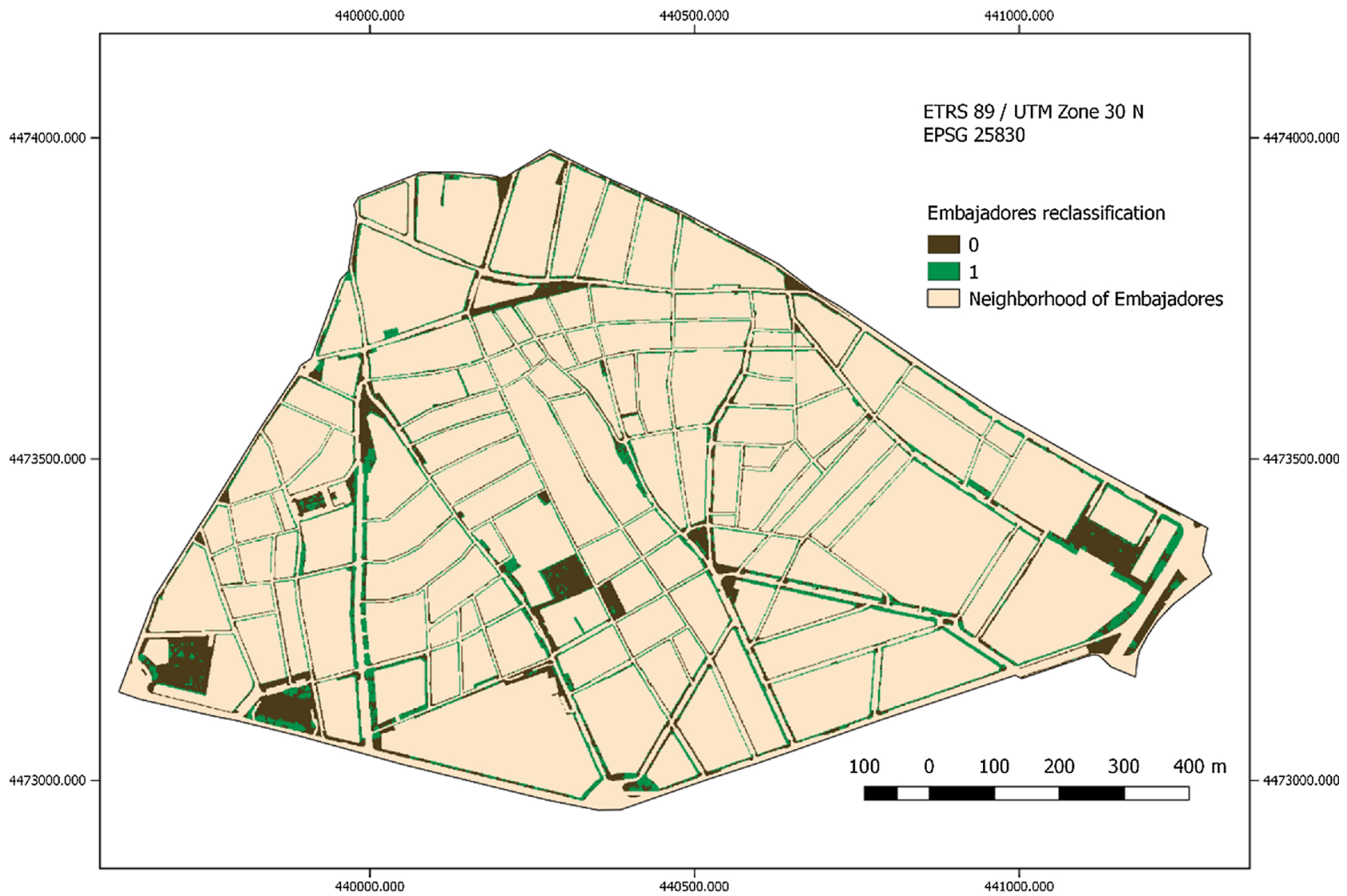

Fig. 6. Urban trees of Embajadores showing the reclassified data (Values: $0=$ pedestrian areas; $1:$ tall tree areas (4-5 m)).

benefits generated by green areas in urban environments (Fraser and Kenney, 2000; Luck et al., 2009). This lack of green areas is also repeated in the suburbs in the west and southwest parts of the city. This is mainly due to the fact that historically peripheral neighborhoods were destined more for industry, production and commerce instead of residence, so there was less need to install green spaces (Wolch et al., 2014; Amati, 2016; Schetke et al., 2016).

It is important to mention the special case of El Pardo neighborhood. This neighborhood is located in a relatively natural environment, and its forest stands are not included in the categorization of green areas. This neighborhood has few buildings, very few people and large masses of vegetation, which practically rules it out for the location of green roofs.

\subsubsection{Variable 3. Traffic}

The highest percentage of traffic is recorded in the peripheral neighborhoods (Fig. 3c)) through which the main beltways and several highways (that connect the center with the east of the country) run. These roads have a very high traffic volume because they are the access points to the city center. Although traffic in the city center is much smaller by comparison, the number of vehicles that travel on its roads is very large. Madrid is the city in Spain with the highest traffic intensity, and one of the busiest cities in Europe (Kassomenos et al., 2014; Laña et al., 2016). The influence of traffic on human health is much greater in the central zone (even though traffic levels are lower than on the periphery), since the arrangement of the buildings prevents the dispersion of pollutants, causing excessive accumulation (Eeftens et al., 2013).

\subsubsection{Variable 4. Population}

The highest population densities are located in the downtown area of the city, with the peripheral neighborhoods the least populated (Fig. 3d)). This is due to the fact that the number of housing units in the central districts is higher than that of the peripheral districts. Taking this population density data into account, green roofs will benefit a greater number of people if they are installed in the more central neighborhoods (Norton et al., 2015; Vijayaraghavan, 2016).

\subsubsection{Neighborhood selection}

After reclassifying the data for the different variables, we proceeded to select the neighborhoods by means of a weighted linear summation. The weights that were given to each variable were those obtained in the expert consultation (Table 1).

After carrying out the weighted linear summation for each neighborhood, the scores were obtained. The neighborhoods with higher scores were given preference when it came to determining the location of the green roofs. The neighborhood of the Historic District of Vallecas was the one with the highest score. This is due to the large amount of traffic in that neighborhood. Despite this, it had quite low population values and the number of buildings was very small, so this neighborhood was ruled out. As for the rest of the neighborhoods, those that both presented higher scores and belonged to different districts were selected to expand the area of action (Table 2 and Fig. 4).

Gaztambide, Ibiza, Goya, Opañel and Embajadores were selected from the 10 neighborhoods with the highest scores. The Historic District of Vallecas was ruled out for the reasons described above, along with the neighborhood of Arapiles because it is located in the same district as Gaztambide.

\subsection{Phase 2. Roof selection}

\subsubsection{Variable 5. Height of buildings}

Once the overall height data from the LIDAR of the city of Madrid and the DTM of the study area had been processed together, the heights of the buildings of each neighborhood were obtained, Digital Elevation 


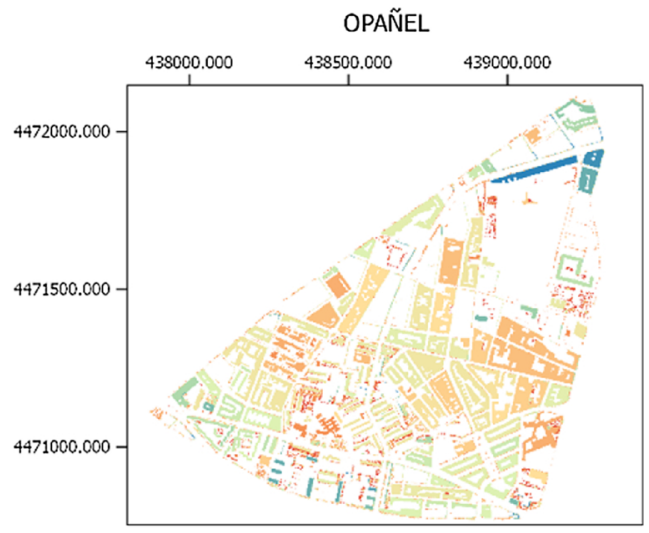

$150 \quad 0 \quad 150300450 \mathrm{~m}$

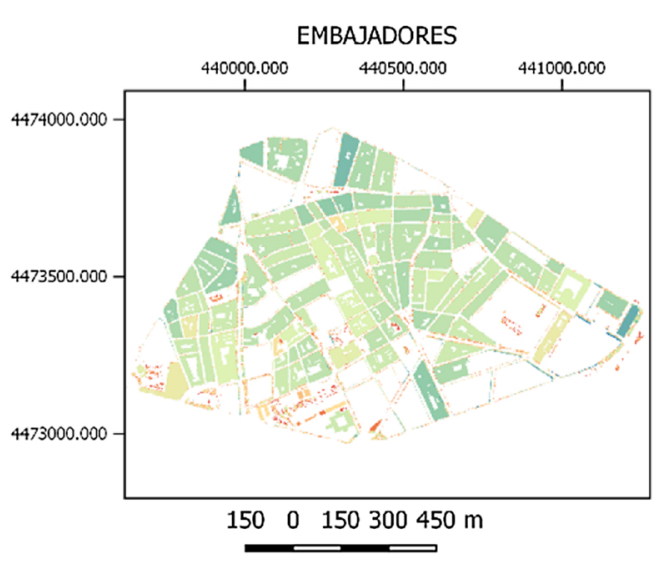

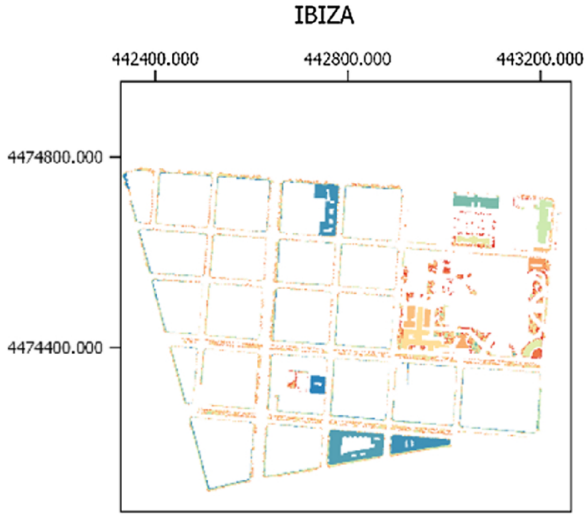

$150 \quad 0 \quad 150300450 \mathrm{~m}$

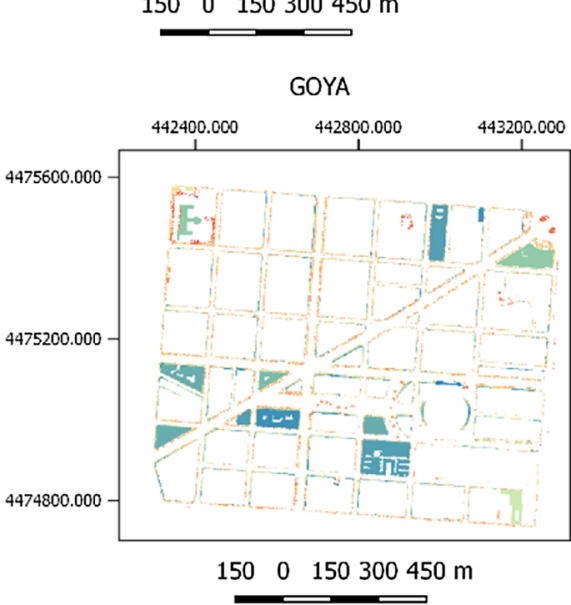

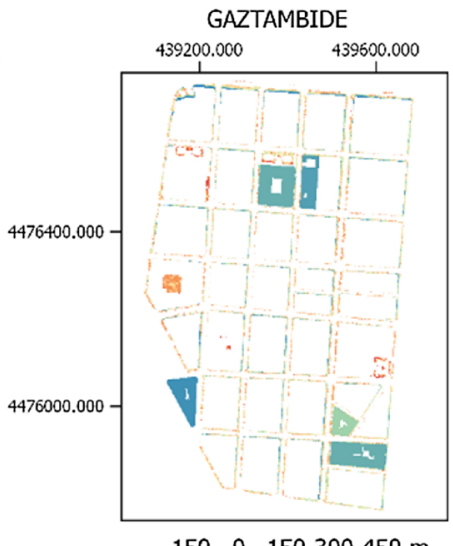

$150 \quad 0 \quad 150300450 \mathrm{~m}$
MSPA input

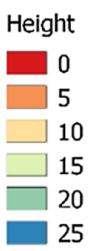

ETRS 89 / UTM Zone 30N EPSG 25830

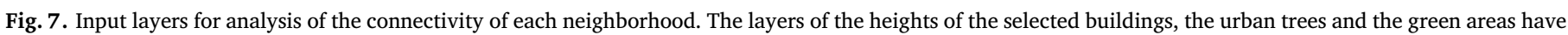
been combined.

Table 4

Data from the MSPA analysis in the selected neighborhoods of Madrid.

\begin{tabular}{|c|c|c|c|c|c|}
\cline { 2 - 6 } \multicolumn{1}{c|}{} & EMBAJADORE & GAZTAMBID & GOYA & IBIZA & OPANEL \\
\hline CORE & $81.62 \%$ & $51.97 \%$ & $50.88 \%$ & $48.22 \%$ & $70.61 \%$ \\
\hline ISLET & $1.53 \%$ & $4.33 \%$ & $4.35 \%$ & $6.20 \%$ & $1.97 \%$ \\
\hline PERFORATION & $2.58 \%$ & $0.89 \%$ & $0.85 \%$ & $1.38 \%$ & $3.20 \%$ \\
\hline EDGE & $9.89 \%$ & $24.71 \%$ & $25.19 \%$ & $25.20 \%$ & $17.50 \%$ \\
\hline LOOP & $1.41 \%$ & $1.83 \%$ & $1.95 \%$ & $2.31 \%$ & $1.18 \%$ \\
\hline BRIDGE & $0.85 \%$ & $8.76 \%$ & $8.70 \%$ & $8.51 \%$ & $1.84 \%$ \\
\hline BRANCH & $2.11 \%$ & $7.51 \%$ & $8.08 \%$ & $8.19 \%$ & $3.71 \%$ \\
\hline
\end{tabular}

Model, DEM (Sohn and Dowman, 2003). The average height of the DEM was used to determine which buildings were within the range of heights desired for the green roofs; and based on the standard deviation, buildings with flat roofs that allows installation of green roofs were chosen (Oberndorfer et al., 2007) (Table 3).

Finally, those buildings that fulfilled the desired characteristics were selected: height between 4 and $25 \mathrm{~m}$ (Sugumaran and Voss, 2007) and a standard deviation of less than $5 \mathrm{~m}$ (Rottensteiner et al., 2005; Kim and Shan, 2011) (Fig. 5). In the neighborhoods of Opañel and Embajadores, there are many buildings that fulfil the aforementioned requirements; on the other hand, in Ibiza, Gaztambide and Goya, the number of available buildings is lower, but is also feasible.

\subsubsection{Variable 6. Urban trees}

The urban trees located on the sidewalks of the neighborhoods of Madrid vary in height. The maximum height that the trees reach is between 20 and $25 \mathrm{~m}$, connecting perfectly with the selected buildings.

When reclassifying the data of the raster layer that contains the trees, the trees located on the sidewalks that have a height between 4 and $50 \mathrm{~m}$ were selected, assigning a value of 1 (see the example of the calculation of urban tree canopy based on LiDAR for Embajadores neighborhood in Fig. 6). As observed, most of the sidewalk trees are represented in green. However, the large pedestrian areas of the neighborhood are mostly brown, which corresponds to a value of 0 . As these are pedestrian zones, such as squares or gardens, most of the surface area has been cleared for the enjoyment of pedestrians, but that does not exclude the presence of some green dots, which correspond to large trees.

\subsubsection{Variable 7. Connectivity}

In order to calculate connectivity using the MSPA index, it was necessary to calculate the buildings selected in each neighborhood with 

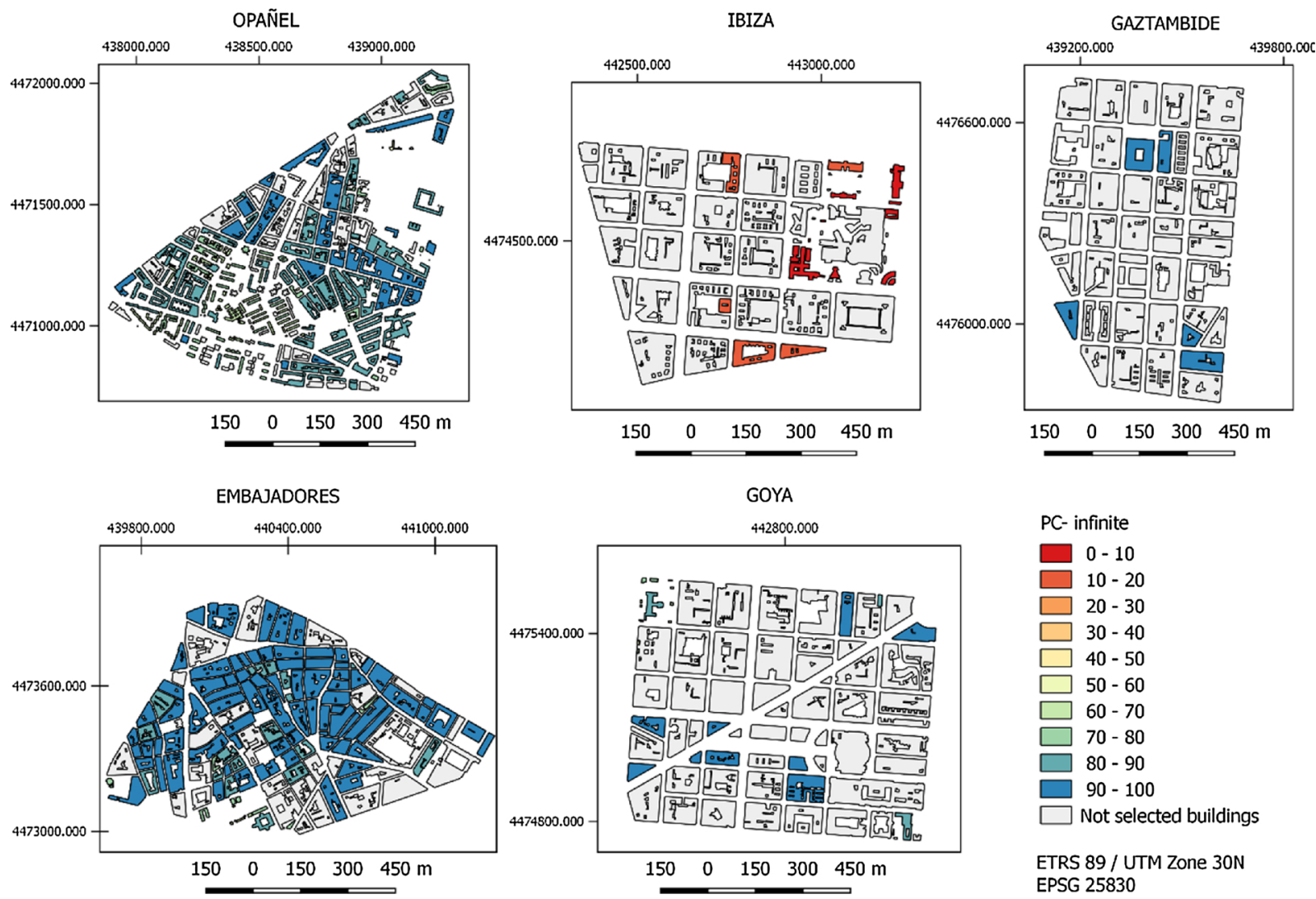

Fig. 8. PC-infinite of the proposed buildings of each neighborhood.

urban trees and green areas together in raster format (Fig. 7). The use of this novel MSPA index in the study of connectivity of urban green areas provides basic information to support the planning of the green space network (Chang et al., 2014).

After the processing of the input data (selected buildings, green areas and urban trees), the following results of the MSPA analysis were obtained for the different neighborhoods selected in phase one. In the Embajadores neighborhood, $81.62 \%$ of the components were classified as nodes. These nodes, which have a larger area, correspond to the roofs of the buildings selected as green roof locations. Perforations are observed inside some nodes $(2.58 \%)$. Thanks to the points of connectivity generated by urban trees, these were classified mostly as bridges $(0.85 \%)$, loops $(1.41 \%)$ and branches $(2.11 \%)$. On the other hand, $1.53 \%$ of the components correspond to islands, located in areas of urban trees that are too isolated to connect. The remaining $9.89 \%$ are the edges of large areas, such as nodes. The situation is similar in the other neighborhoods. The difference is that the percentage of nodes in the neighborhoods of Gaztambide, Goya and Ibiza is around 50\%, a lower value than in the neighborhood of Embajadores.

The smaller number of buildings selected influences the percentage of nodes, which translates into an increase in the percentage of edges (around 25\%). The urban trees continue to behave mostly as points of connectivity (bridges, loops and branches). The Opañel neighborhood has a large number of roofs available, which means that, as in the case of Embajadores, the percentage of nodes is very high (70.61\%). Consequently, the percentage of edge is reduced (17.5\%) and urban trees act primarily as connections (Table 4).

Once the MSPA analysis was performed, we evaluated the importance of each element for connectivity using the PC-infinite index. The PC index assesses the importance of each link and each node for maintaining connectivity (Saura and Pascual-Hortal, 2007; Hernando et al., 2017).

Of all the districts studied (Embajadores, Gaztambide, Goya, Ibiza and Opañel), the highest PC value was obtained by a building in the Goya neighborhood, with a value of 170.09 (this maximum value was used to reclassify the data of the 1-100). Most of the buildings of Embajadores presented connectivity probabilities higher than $87.4 \%$, while only 21 of the 111 total had a connectivity value between $31.0 \%$ and $87.4 \%$. It is therefore possible to say that the installation of green roofs in the Embajadores neighborhood would improve functional connectivity. The case of Gaztambide, Opañel and Goya is very similar. In Gaztambide, all of the buildings presented connectivity values higher than $92 \%$, and in Opañel, the majority exceeded $82.9 \%$. In the neighborhood of Goya, the range of values was wider, but most of the buildings presented connectivity values higher than $90.8 \%$. The neighborhood that undoubtedly presented the worst results was Ibiza. The maximum value barely reached $15 \%$, so the connectivity of these buildings is quite small due to the weaker network formed by the buildings and urban tree canopy in this neighborhood, as shown in Fig. 7. It is clear that in Ibiza, the improvement of connectivity would not be notable for the fauna and flora of Madrid, but the neighborhood's data regarding pollution, traffic and green areas make it necessary to install these roofs to improve its environmental quality (Fig. 8).

\subsubsection{Roof selection}

The analysis of the variables in phase two made it possible to select the optimal locations for the installation of green roofs. To do this, the buildings that showed a higher value of PC-infinite, indicating their function as an important component for providing connectivity, and met the previous criteria indicated in phase 2 were selected (Fig. 9)

In the neighborhoods of Embajadores, Gaztambide, Goya and Opañel, roofs with PC-infinite values higher than $90 \%$ were selected; in Ibiza, due to the low values recorded, roofs with PC-infinite values greater than $7 \%$ were selected (based on the quantile distribution of PCinfinite values).

In the Embajadores neighborhood, 79 roofs fulfilled the established 

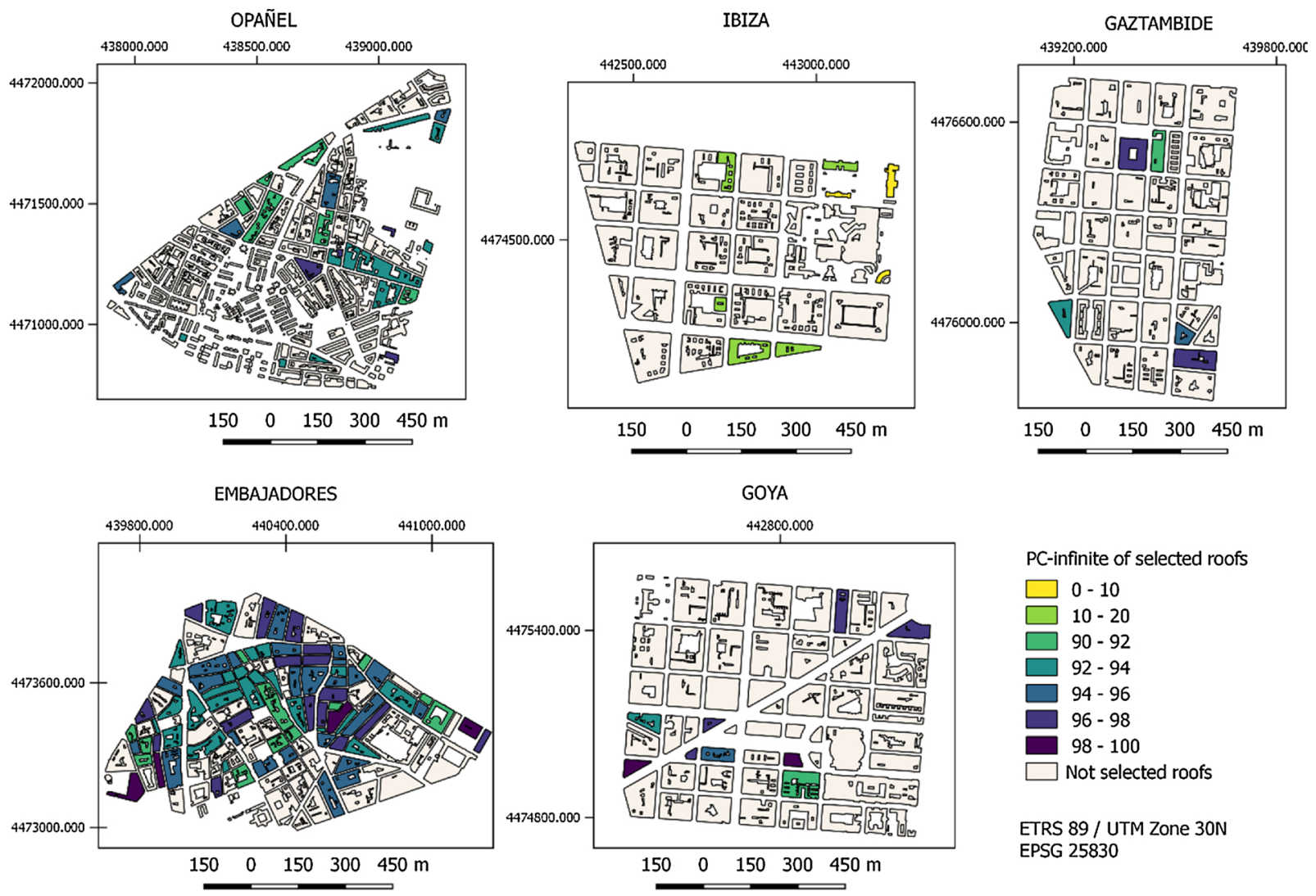

Fig. 9. PC-infinite of the buildings ultimately selected in each neighborhood.

conditions of connectivity, presenting very good conditions for the location of green roofs. In the case of Gaztambide, 5 of the 5 buildings proposed met the connectivity requirements of more than $90 \%$, and in the Goya district 9 of 22 buildings fulfilled the requirements. In the Opañel neighborhood, on the other hand, of the 179 buildings, only 25 exceeded 90\% connectivity. Despite this, most buildings presented PCinfinite values of over $70 \%$, Opañel can be said to have good connectivity. Finally, in the neighborhood of Ibiza 8 roofs of the 17 analyzed were selected. The connectivity of these roofs was very low compared to the rest of the neighborhood and although the connectivity benefits were not very significant, the environmental conditions of the neighborhood would be improved with the installation of green roofs.

\section{Conclusions}

The planning of green roofs in large cities requires the knowledge of various variables to select the best locations. By jointly managing the main variables that affect urban pollution, it is possible to select the areas in which green roofs are needed to mitigate pollution, and therefore, generate greater benefits with the implementation of green roofs. It is especially interesting to focus not only on the neighborhoods in which green roofs can be installed, but also to find the optimal locations. These optimal locations will be determined by selecting the roofs with the potential for the installation of these facilities and in turn improve the network of green spaces, favoring connectivity.

At the specific level, the analysis of the different variables selected in this study (pollution, traffic, green areas and population) provides an overall perspective of the environmental situation of a large city such as Madrid. The most central neighborhoods are those with the worst pollution values, due to the intense levels of human activity in them and the difficulty of dispersion of pollutants as a result of urban design. The situation in terms of green areas is similar; the downtown neighborhoods have a lower proportion of landscaped spaces. The traffic intensity in the city center is extremely high, so much so that Madrid is the city in Spain with the highest traffic intensity of vehicles. This data, together with the population density (which tends to be located in the downtown areas), allows us to conclude that the most problematic neighborhoods from the environmental point of view are those located in the center of the city, which makes them ideal locations for green roofs.

Once the neighborhoods in which action is necessary have been selected, the height and standard deviation of the buildings in those neighborhoods are analyzed to choose the roofs that have heights similar to those of the urban trees and that have flat surfaces for correct installation. This helps to improve the connectivity of the green spaces of Madrid, promoting the dispersion of plant and animal species that inhabit this environment. It is a simple but effective method that will allow large cities to determine the best places to install green roofs and promote sustainable and quality urban development.

\section{References}

Ahern, J., 2007. Green infrastructure for cities: the spatial dimension. In Cities of the Future: Towards Integrated Sustainable Water and Landscape Management. IWA Publishing.

Aiello, F., Grande, F., Sticozzi, C., Valacchi, G., 2015. Outdoor air pollutants. Studies on Experimental Toxicology and Pharmacology. Springer International Publishing, pp. 303-321.

Amati, M. (Ed.), 2016. Urban Green Belts in the Twenty-First Century. Routledge.

Arozarena, A., Villa, G., Valcárcel, N., 2005. The national aerial ortophoto program in Spain (PNOA). International Cartographic Conference.

Articte, P.N., 1995. Raster procedures for multi-criteria/multi-obiective decisions. Photogram. Eng. Remote Sens. 61 (5), 539-547.

Baudry, J., Merriam, H.G., 1988. "Connectivity and connectedness: functional versus structural patterns in landscapes". Schreiber, K.F. (Ed.), Connectivity in Landscape Ecology (Edited by Proceedings of the 2nd International Seminar of the International Association of Landscape Ecology 23-28.

Beelen, R., Hoek, G., Vienneau, D., Eeftens, M., Dimakopoulou, K., Pedeli, X., et al., 2013. Development of NO 2 and NO $\mathrm{x}$ land use regression models for estimating air pollution exposure in 36 study areas in Europe-the ESCAPE project. Atmos. Environ. 72, 10-23.

Berardi, U., GhaffarianHoseini, A., GhaffarianHoseini, A., 2014. State-of-the-art analysis of the environmental benefits of green roofs. Appl. Energy 115, 411-428.

Blocken, B., Stathopoulos, T., Saathoff, P., Wang, X., 2008. Numerical evaluation of 
pollutant dispersion in the built environment: comparisons between models and experiments. J. Wind Eng. Ind. Aerodyn. 96 (10-11), 1817-1831.

Brenneisen, S., 2006. Space for urban wildlife: designing green roofs as habitats in Switzerland. Urban Habitats 4 (1), 27-36.

Breuste, J.H., Qureshi, S., Fei, X.U.E., 2014. Urban Ecosystems: Functions, Services and Sustainable Management. Eco-city and Green Building, Beijing, pp. 42-52 4.

Britter, R.E., Hanna, S.R., 2003. Flow and dispersion in urban areas. Annu. Rev. Fluid Mech. 35 (1), 469-496.

Chang, Q., Liu, X., Wu, J., He, P., 2014. MSPA-based urban green infrastructure planning and management approach for urban sustainability: case study of Longgang in China. J. Urban Plan. Dev. 141 (3), A5014006.

Chiesura, A., 2004. The role of urban parks for the sustainable city. Landsc. Urban Plan. 68 (1), 129-138.

Chun, B., Guldman, J.M., 2014. Spatial statistical analysis and simulation of the urban heat island in high-density central cities. Landsc. Urban Plan. 125, 76-88.

Constanzo, V., Evola, G., Marletta, L., 2016. Energy savings in buildings or UHI mitigation? Comparison between green roofs and cool roofs. Energy Buld. 114, 247-255.

Currie, B.A., Bass, B., 2008. Estimates of air pollution mitigation with green plants and green roofs using the UFORE model. Urban Ecosyst. 11 (4), 409-422.

DeMers, M.N., 2002. GIS Modeling in Raster (No. 910.285 D4G5). Wiley, New York.

Eeftens, M., Beekhuizen, J., Beelen, R., Wang, M., Vermeulen, R., Brunekreef, B., et al., 2013. Quantifying urban street configuration for improvements in air pollution models. Atmos. Environ. 72, 1-9.

Fraser, E.D., Kenney, W.A., 2000. Cultural background and landscape history as factors affecting perceptions of the urban forest. J. Arboric. 26 (2), 106-113.

García, F.F., 1999. Contaminación atmosférica en Madrid y su área metropolitana.

Getter, K.L., Rowe, D.B., 2006. The role of extensive green roofs in sustainable development. HortScience 41 (5), 1276-1285.

Grimm, N.B., Faeth, S.H., Golubiewski, N.E., Redman, C.L., Wu, J., Bai, X., Briggs, J.M., 2008. Global change and the ecology of cities. Science 319, 756-760.

Haaland, C., van den Bosch, C.K., 2015. Challenges and strategies for urban green-space planning in cities undergoing densification: a review. Urban For. Urban Green. 14 (4), 760-771.

Hernando, A., Velázquez, J., Valbuenta, R., Legrand, M., García-Abril, A., 2017. Influence of the resolution of forest cover maps in evaluating fragmentation and connectivity to assess habitat conservation status. Ecol. Indic. 79, 295-302.

Huang, S.L., Wong, J.H., Chen, T.C., 1998. A framework of indicator system for measuring Taipei's urban sustainability. Landsc. Urban Plan. 42 (1), 15-27.

Isenburg, M., 2015. LAStools-efficient Tools for LiDAR Processing, version 150304 .

James, P., Tzoulas, K., Adams, M.D., Barber, A., Box, J., Breuste, J., et al., 2009. Towards an integrated understanding of green space in the European built environment. Urban For. Urban Green. 8 (2), 65-75.

Kampa, M., Castanas, E., 2008. Human health effects of air pollution. Environ. Pollut. 151 (2), 362-367.

Kanaroglou, P.S., Jerrett, M., Morrison, J., Beckerman, B., Arain, M.A., Gilbert, N.L., Brook, J.R., 2005. Establishing an air pollution monitoring network for intra-urban population exposure assessment: a location-allocation approach. Atmos. Environ. 39 (13), 2399-2409.

Karachaliou, P., Santamouris, M., Pangalou, H., 2016. Experimental and numerical analysis of the energy performance of a large scale intensive green roof system installed on an office building in Athens. Energy Build. 114, 256-264.

Kassomenos, P.A., Vardoulakis, S., Chaloulakou, A., Paschalidou, A.K., Grivas, G., Borge, R., Lumbreras, J., 2014. Study of PM 10 and PM 2.5 levels in three European cities: analysis of intra and inter urban variations. Atmos. Environ. 87, 153-163.

Kim, K., Shan, J., 2011. Building roof modeling from airborne laser scanning data based on level set approach. ISPRS J. Photogram. Remote Sens. 66 (4), 484-497.

Krugman, P., 1993. On the number and location of cities. Eur. Econ. Rev. 37 (2-3), 293-298.

Kuchelmeister, G., 2000. Trees for the Urban Millennium: Urban Forestry Update. UNASYLVA-FAO-, pp. 49-55.

Laña, I., Del Ser, J., Padró, A., Vélez, M., Casanova-Mateo, C., 2016. The role of local urban traffic and meteorological conditions in air pollution: a data-based case study in Madrid, Spain. Atmos. Environ. 145, 424-438.

Le Roux, D.S., Ikin, K., Lindenmayer, D.B., Manning, A.D., Gibbons, P., 2014. The future of large old trees in urban landscapes. Plos One 9 (6), e99403.

Leva, G., 2005. Indicadores de calidad de vida urbana. Teoría y metodología.

Li, Y., Babcock, R.W., 2014. Green roofs against pollution and climate change. A review. Agron. Sustain. Dev. 34 (4), 695-705.

Li, J.F., Wai, O.W., Li, Y.S., Zhan, J.M., Ho, Y.A., Li, J., Lam, E., 2010. Effect of green roof on ambient CO2 concentration. Build. Environ. 45 (12), 2644-2651.

Lopera, F.G., 2005. Las zonas verdes como factor de calidad de vida en las ciudades. Ciudad y Territorio Estudios Territoriales 37 (144), 417.

Luck, G.W., Smallbone, L.T., O'Brien, R., 2009. Socio-economics and vegetation change in urban ecosystems: patterns in space and time. Ecosystems 12 (4), 604.

Malczewski, J., 2006. GIS-based multicriteria decision analysis: a survey of the literature. Int. J. Geogr. Inf. Sci. 20 (7), 703-726 Helbing, D., 2001. Traffic and related selfdriven many-particle systems. Reviews of modern physics, 73(4), 1067.

Mattoni, B., Gugliermetti, F., Bisegna, F., 2015. A multilevel method to assess and design the renovation and integration of smart cities. Sustain. Cities Soc. 15, 105-119.

Minke, G., 2004. Techos Verdes. Planificación, ejecución, consejos prácticos, Montevideo, Uruguay (Ed.) Fin de Siglo.

Miranda, A.I., Martins, H., Valente, J., Amorim, J.H., Borrego, C., Tavares, R., Samson, R., del Amo, R.A., 2017. Case studies: modeling the atmospheric benefits of urban greening. The Urban Forest. Springer International Publishing, pp. 89-99.

Municipality of Madrid, 2016. Inventario Municipal del arbolado urbano de Madrid.

Norton, B.A., Coutts, A.M., Livesley, S.J., Harris, R.J., Hunter, A.M., Williams, N.S., 2015. Planning for cooler cities: a framework to prioritise green infrastructure to mitigate high temperatures in urban landscapes. Landsc. Urban Plan. 134, 127-138.

Oberndorfer, E., Lundholm, J., Bass, B., Coffman, R.R., Doshi, H., Dunnett, N., Rowe, B., 2007. Green roofs as urban ecosystems: ecological structures, functions, and services.
BioScience 57 (10), 823-833.

Peck, S.W., 2009. Toronto City Council Adopts Mandatory Green Roof Requirements. Green Roofs for Healthy Cities, Toronto p 1.

Peiró, M.N., Sánchez, C.S.G., González, F.J.N., 2017. Update of the Urban Heat Island of Madrid and its influence on the building's energy simulation. Sustainable Development and Renovation in Architecture, Urbanism and Engineering. Springer International Publishing, pp. 339-350.

Querol, X., Alastuey, A., Pandolfi, M., Reche, C., Pérez, N., Minguillón, M.C., Moreno, T., Viana, M., Escudero, M., Orio, A., Pallarés, M., Reina, F., 2014. 2001-2012 trends on air quality in Spain. Sci. Total Environ. 490, 957-969.

Razzaghmanesh, M., Beecham, S., Salemi, T., 2016. The role of green roofs in mitigating Urban Heat Islands effects in the metropolitan area of Adelaide, South Australia. Urban For. Urban Green. 15, 89-102.

Roman, K.K., O'Brien, T., Alvey, J.B., Woo, O., 2016. Simulating the effects of cool roof and PCM (phase change materials) based roof to mitigate UHI (urban heat island) in prominent US cities. Energy 96, 103-117.

Rottensteiner, F., Trinder, J., Clode, S., Kubik, K.K.T., 2005. Automated delineation of roof planes from lidar data. ISPRS Workshop Laser Scanning 2005 Vol. 36, 221-226 ISPRS Workshop groups WG III/3, III/4, V/3. Hernández Aja, A., 2009. Calidad de vida y Medio Ambiente Urbano: indicadores locales de sostenibilidad y calidad de vida urbana. Revista Invi, 24(65), 79-111.

Rowe, D.B., 2011. Green roofs as a means of pollution abatement. Environ. Pollut. 159 (8), 2100-2110.

Saaty, T., 1980. The Analytic Hierarchy Pocess. McGrawHill.

Sanesi, G., Chiarello, F., 2006. Residents and urban green spaces: the case of Bari. Urban For. Urban Green. 4 (3-4), 125-134.

Saura, S., Pascual-Hortal, L., 2007. A new habitat availabiity index to integrate connectivity in landscape conservation planning: comparison with existing indices and application to a case study. Landsc. Urban Plan. 83, 91-103.

Saura, S., Vogt, P., Velázquez, J., Hernando, A., Tejera, R., 2011. Key structural connectors can be identified by combining landscape spatial pattern and network analyses. For. Ecol. Manage. 262, 150-160.

Schetke, S., Qureshi, S., Lautenbach, S., Kabisch, N., 2016. What determines the use of urban green spaces in highly urbanized areas?-Examples from two fast growing Asian cities. Urban For. Urban Green. 16, 150-159.

Shanahan, D.F., Fuller, R.A., Bush, R., Lin, B.B., Gaston, K.J., 2015. The health benefits of urban nature: how much do we need? BioScience 65 (5), 476-485.

Sims, A.V., Robinson, C.E., Smart, C.C., Voogt, J.A., Hay, G.J., Lundholm, J.T., Powers, B., O'Carrol, D.M., 2016. Retention performance of green roofs in three different climate regions. J. Hidrol. 542, 115-124.

Sohn, G., Dowman, I., 2003. Building extraction using Lidar DEMs and Ikonos images. Int. Arch. Photogram. Remote Sens. 34 (3), 37-43.

Song, X.P., Richards, D., Edwards, P., Tan, P.Y., 2017. Benefits of trees in tropical cities. Science 356 (6344) 1241-1241.

Stern, E., Krakover, S., 1993. The formation of a composite urban image. Geogr. Anal. 25 (2), 130-146.

Sugumaran, R., Voss, M., 2007. Object-oriented classification of LIDAR-fused hyperspectral imagery for tree species identification in an urban environment. Urban Remote Sensing Joint Event, 2007. pp. 1-6 IEEE.

Tanguay, G.A., Rajaonson, J., Lefebvre, J.F., Lanoie, P., 2010. Measuring the sustainability of cities: an analysis of the use of local indicators. Ecol. Indic. 10 (2), 407-418.

Taylor, P.D., Fahrig, L., Henein, K., Merriam, G., 1993. Connectivity is a Vital Element of Landscape Structure, Oikos. no 68. pp. 571-573.

Toronto City Planning Division, 2013. Green Roof By-Law. City of Toronto Planning Division, Toronto. Avaliable:. http://www.toronto.ca/legdocs/municode/1184_492. pdf.

Tripathi, A.K., Gautam, M., 2007. Biochemical parameters of plants as indicators of air pollution. J. Environ. Biol. 28 (1), 127.

Tumini, I., 2010. Estrategias para reducción del efecto isla de calor en los espacios urbanos. Estudio aplicado al caso de Madrid. Ponencia SB10 MAd. Edificación sostenible. Revitalización y Rehabilitación de Barrios, Madrid, España.

Tyrväinen, L., Ojala, A., Korpela, K., Lanki, T., Tsunetsugu, Y., Kagawa, T., 2014. The influence of urban green environments on stress relief measures: a field experiment. J. Environ. Psychol. 38, 1-9.

Ulmer, J.M., Wolf, K.L., Backman, D.R., Tretheway, R.L., Blain, C.J., O'Neil-Dunne, J.P., Frank, L.D., 2016. Multiple health benefits of urban tree canopy: the mounting evidence for a green prescription. Health \& Place 42, 54-62.

United Nations, 2013. World Population Prospects: the 2012 Revision. Population division of the department of economic and social affairs of the United Nations Secretariat, New York.

Velázquez, J., Gutiérrez, J., Hernando, A., García-Abril, A., 2017. Evaluating landscape connectivity in fragmented habitats: cantabrian Capercaillie (Tetrao urogallus cantabricus) in northern Spain. For. Ecol. Manage. 262, 150-160.

Vijayaraghavan, K., 2016. Green roofs: a critical review on the role of components, benefits, limitations and trends. Renew. Sustain. Energy Rev. 57, 740-752.

Vogt, P., 2009. MSPA-GUIDOS: Innovative Methods in Landscape Pattern Analysis. Institute for Environment and Sustainability.

Vogt, P., Riitters, K., 2017. GuidosToolbox: universal digital image object analysis. Eur. J. Remote Sens. 50 (1), 352-361.

Willis, K.J., Petrokofsky, G., 2017. The natural capital of city trees. Science 356 (6336), 374-376.

Wolch, J.R., Byrne, J., Newell, J.P., 2014. Urban green space, public health, and environmental justice: the challenge of making cities 'just green enough'. Landsc. Urban Plan. 125, 234-244.

Yang, J., Yu, Q., Gong, P., 2008. Quantifying air pollution removal by green roofs in Chicago. Atmos. Environ. 42 (31), 7266-7273.

Ziogou, I., Michopoulos, A., Voulgari, V., Zachariadis, T., 2017. Energy, environmental and economic assessment of electricity savings from the operation of green roofs in urban office buildings of a warm Mediterranean region. J. Clean. Prod. 168, 346-356. 